\title{
Corporate Social Responsibility and Bank Performance: A Cointegration Approach
}

\author{
John Gartchie Gasti ${ }^{1}$, Joseph Ameyibor ${ }^{2}$ \& Edward Quansah ${ }^{3}$ \\ ${ }^{1,2,3}$ Department of Finance, School of Business, University of Cape Coast \\ Email:.jgasti@ucc.edu.gh
}

\begin{abstract}
The aim of this study is to examine the short- and the long-run effects of Corporate Social Responsibility (CSR) on the performance of listed Ghanaian banks. An elongated balanced panel design with secondary data of 65 years' bank observations spanning 2004 to 2016 was used for the study. A cointegration approach - Pooled Mean Group (PMG/Panel ARDL) was used to examine the short- and the long-term effects of CSR on bank performance while controlling for bank variability, growth in interest income and bank size. The results were mixed. In the short term, it was found that CSR has positive but insignificant effect on bank performance (market-to-book value). In the long-term, however, CSR has significant negative effect on bank performance. Based on the findings, the study concludes that, in the long run, engaging in CSR reduces bank
\end{abstract}

performance. Therefore, CSR needs to be carefully planned and implemented to serve as a boost to bank performance and not just regarded as an inconsequential addendum.

Keywords: Bank performance, corporate social responsibility, cointegration approach 


\section{Introduction}

Corporate

Social

Responsibility (CSR) from its inception has been seen as businessmen's obligation to pursue policies, to make decisions, or to follow the lines of action, which are desirable in terms of the objectives and values of society (Bowen, 1953). From this position, CSR became a valid theme and businesses that continue to increase their corporate social expenditures always increase their performance. In 2011, corporate donations in the U.S amounted to \$ 14.6 billion, representing a $61.3 \%$ increase (Giving U. S. A., 2012), while in China, the donations constitute about 58.1\% (Zhang, Yang, Wang \& Wang, 2012). The concept of CSR consciousness led to both the Shareholder and the Stakeholder theories (Orlitzky, 2005). According to Ahmed, Islam and Hasan (2012), managers have found economic benefits from CSR programmes, considering that the objective of a business is to maximize shareholders' wealth. It is also an important medium for creating sustainable competitive advantages at both national and company levels (Vilanova, Lozano \& Arenas, 2009). Similarly, Saleh,
Zulkifli and Muhamad (2010) argued that CSR is a powerful tool to attract and maintain institutional investors.

From what began in corporate boardrooms, the CSR concept has become a common household name and recognised by most organisations, including financial institutions, such as banks. The banking sector does not only drive economic growth through mobilisation and disbursement of facilities, but also ensure performance efficiency for shareholders (Hye \& Dolgopolova, 2011). To achieve all these, they need to develop strategies that account for wider societal concerns arising from their business operations. Within the banking sector, therefore, CSR becomes a harmonizing tool that banks use to positively impact performance. According to Lentner, Szegedi and Tibor (2015), a bank's stable financial position, increasing economic performance, ethical and transparent activities, within the domain of CSR, ensure predictable and reliable operations, and serve the interests of society to a larger degree.

Business benefits of CSR are not only oriented in the shortterm, but also in the long term. Most pioneering studies pointed to this 
direction. Amran, Ling, and Sofri (2007) stated that public listed companies in Malaysia need to integrate CSR in their company's business activities to remain sustainable in the long-term. Similarly, Carroll and Shabana (2010) held the view that if businesses are to function in the future, they must take actions now that will ensure their long-term viability. The position is not different in the investor market (see Barnett \& Salomon, 2003; Mackey, Mackey \& Barney, 2007). Yet, empirical studies on the subject have largely focused on the short term (see Doh, Howton, Howton, \& Siegel, 2010; McGuire, Sundgren \& Schneeweis, 1988; Orlitzky, Schmidt \& Rynes, 2003; Waddock \& Graves, 1997) to the disadvantage of long-term perspectives. This, therefore, makes relevant the arguments by Hazlitt (1952) that serious analytic errors occur when long-run consequences of short-run policies are forgotten (Wible, 1982).

In this respect, the long-term consequences of CSR remained unacknowledged (Orliztky, 2013) and have to be determined. In doing this, the current study took into account the findings of GarciaCastro, Arino and Canela (2010) that the heterogeneous results found in previous works could be more fundamentally related to endogeneity of social strategic decisions, since some of the results found in previous research changed, and some even reversed when endogeneity was properly taken into account.

Developments on CSR in emerging economies in Africa, and, in particular, Ghana, differ in purpose from their western counterparts, and geared towards prudence and not necessarily because it is an obligation (Tuokuu \& Amponsah-Tawiah, 2016). In a similar vein, banks' community undertakings in terms of completion of classroom blocks, health posts, boreholes or provision of educational services are not just visible in the newspapers and annual reports, but also on banks' websites (Hinson \& Adjasi, 2009; Hinson, Boateng \& Madichie, 2010). These occurrences reinforced the case that Ghana's financial sector companies embraced the CSR ideology and the practice is not uncommon.

The fact is, Ghana's banking environment has become more competitive, regulated and capital intensive, and so banks need multinotched approaches to ensure maximum return to shareholders or 
risk collapse. In this regard, every trace of perceived useful opportunities that banks could hold on are adopted. It is not surprising that Ghana Banking Awards feature CSR as one of the key criteria. In the $16^{\text {th }}$ edition of 2017, the overall winner, Ecobank Ghana Ltd, was also the winner of the most Corporate Social Responsibility bank in Ghana (Ghana Banking Awards report, 2017). It is also a component of Ghana Beverage Award, which seeks to recognise the contribution of these companies to the sustainability of the environment.

Notwithstanding the giant strides, evidence showed that CSR in Ghana has mainly been examined in its conceptual or normative forms (Ofori \& Hinson, 2007; Tuokuu \& Amponsah-Tawiah, 2016). Empirical studies regarding its impact on specificities, such as performance, reputation and risk, are in their embryonic stage. Other scholars that provided empirical evidence did so in looking at the various dimensions of CSR and how these conform to major CSR models as in Carroll's (1991 \& 1979) frameworks (Hinson, Agbleze \& Kuada, 2013; Kuada \& Hinson, 2012). Again, due to its association with the environment, a survey of the extant literature showed that CSR practices are hugely skewed towards the mining sector. Banks make the highest contributions to social services each year even though capital structure analysts, such as Amidu (2007) and Gatsi (2012), found them to be hugely financed by debt (i.e., $87 \%$ and $80.23 \%$ respectively). Considering that CSR issues are widely recognised among Ghanaian banks but have been understudied in terms of their effect created a gap that is addressed in this study.

\section{Literature Review}

CSR was defined as the obligations of businessmen to pursue those policies, to make those decisions, or to follow those lines of action which are desirable in terms of the objectives and values of our society (Bowen, 1953), and obligation to constituent groups in society other than stockholders and beyond that prescribed by law and union contract (Jones, 1980). Both Bowen (1953) and Jones (1980) saw CSR as actions of businessmen somewhat wider than that covered by their profit or loss position, but within a well restricted boundary. The study, therefore, followed these definitions, because they set clear 
limits within which CSR could be measured or gauged. On the other hand, Palepu, Healy and Peek (2010) explained the concept of performance is to measure businesses ability to generate revenues, profits and cash flows relative to investment. Performance categories include accounting based, market based, and combination of both accounting based and market based (McGuire, Sundgren \& Schneeweis, 1988; Orlitzky, Schmidt \& Rynes, 2003; Waddock \& Graves, 1997).

There are two opposing views about CSR and its association with performance. On the one hand, some practitioners and scholars argue that the sole aim of business organisations is to maximise shareholder value. On the other hand, other practitioners and scholars believe that businesses must assume moral and ethical responsibility and maximise value for all stakeholders. These two opposing views led to the Shareholder theory and Stakeholder theory.

In Levitt (1958), it was argued that social duties and societal welfare were the responsibility of governments instead of businesses. Levitt (1958) viewed businesses' job as taking care of the critical aspect of welfare. Consequently, social performances are seen as distortion to the profit motive that is critical for business success. As Reinhardt and Stavins (2010) concluded, participating in costly CSR activities reduce wages, profits, dividends, stock prices and create difficulty in attracting new capital, because returns are below market averages. In the long-term, harmful signals are sent to equity markets, which might not systematically correlate with companies' economic fundamentals, thus making opportunistic managers incentivized to distort information provided to market participants (Orliztky, 2013).

In two earlier articles, Friedman's (1962, 1970) explicitly elaborated on the field. Especially, in Friedman (1970), it was feared that the action means spending someone else's money for a general social interest and this could reduce returns to stockholders, since corporate executives lacked expertise on how to spend the money. In support, Sundaram and Inkpen (2004) observed that the objective of shareholder value maximization is better, because it is the only objective that leads to decisions that enhance outcomes for all stakeholders. In their view, maximizing the value of 
shareholders' wealth in the long run would maximize the value of the firm and stakeholders at large.

Other pioneering works in finance and economics also agreed that shareholder value maximisation is an accepted objective of the firm (Markowitz, 1952; Modigliani \& Miller, 1958). Consequently, existence of businesses to maximize the sole interests of shareholders is legitimate and socially ingrained, so that beyond the economic view, CSR is at best a misguided advocacy (Jensen, 2001). Similarly, though within the contractual framework, a firm is seen to have implicit and explicit agreement with other stakeholder groups (Coase, 1937), Boatright (1994) as well as Ehrlich (2005) and Fisch (2006) believed that corporate managers have fiduciary responsibility to maximise shareholder wealth, since shareholders have primacy over constituencies or stakeholders (Margolis \& Walsh, 2003). In sum, the shareholder value maximisation logic offers accountable corporations managed by ethical decision makers that create the greatest value for the greatest number of stakeholders (Sundaram \& Inkpen, 2004).

In sharp contrast to the Shareholder theory is the
Stakeholder theory (Freeman, 1984). The theory's principles are rooted in the interface that businesses have with society where serving more than a single stakeholder maximises total value. The Stakeholder approach sees business and society as integrated elements and not separate entities. In fact, Freeman (1994) and Wicks (1996) referred to this as a mistaken idea when businesses take decisions distinct from ethical consideration. Similar arguments have been proposed by Donaldson and Preston (1995) and Harris and Freeman (2008). Therefore, managing for stakeholders involves maximising for wealth (Phillips, Freeman \& Wicks, 2003). This bidirectional approach between business and society in the Stakeholder model is significantly emphasised in the literature, tested and strongly confirmed by many scholars, including Orlitzky et al (2003); Seifert, Morris and Bartkus (2003); and Waddock and Graves (1997).

Although the Stakeholder theory indicates a significant shift from the traditional ideology of wealth distribution, other writers argued that the concepts are not generally developed in ways that make them useful in practice 
(Ackermann \& Eden, 2011). This is similar in context to Jensen's (2001), that Stakeholder theory failed to specify necessary trade-offs among competing interests and make managers unaccountable for their actions.

\section{Review of empirical evidence}

Prior studies on the link between CSR and performance cut across developed and emerging markets, and mainly focused on the short-term perspective. Waddock and Graves (1997) examined the link between corporate social performance and financial performance, using a greatly improved source of data. Controlled variables, including firm size, firm variability and industry effect, were used, because they have been suggested in previous works as factors that affect both firm performance and corporate social performance. The results showed that corporate social performance positively associated with prior financial performance.

Additionally, Godfrey, Merrill and Hansen (2009) investigated whether corporate social performance carries insurance-like properties on market value of negative firm-specifics. In the event study analysis, evidence of risks mitigation by corporate social performance was found, indicating that wealth-protective property of CSR is favoured by targeted secondary stakeholders. Though the methodology was appropriate for discrete idiosyncratic type, focusing only on specific negative events hinders the generalisation of the results. Again, using a similar methodology, but focusing on the effect of corporate social performance on idiosyncratic risk, Luo and Bhattacharya (2009) found the two constructs to be negatively connected.

In Keffas and Olulu-Briggs (2011), financial ratios and frontier efficiency analyses were used to examine the financial performance of CSR and non-CSR banks. Data were sourced from banks in Japan, US and UK listed on the FTSE4Good global index. From the data envelopment analysis, it was found that a positive relationship exists between corporate social responsibility and financial performance. Based on the findings, the authors concluded that incorporating CSR in banks operation leads to better asset quality, capital adequacy and efficient management of portfolios. 
In the same vein, but this time from two different regions, namely the USA and Europe, Von Arx and Ziegler (2014) tested CSRCFP relationship within two different frameworks and disentangled sector specific impacts of CSR, using multifactor models. The econometric analysis showed that CSR activities are valued positively by financial markets in both regions. Additionally, Ciciretti, Kobeissi and Zhu (2014) tested the impact of a bank's community responsibilities on financial performance. After controlling for bank size and bank variability to ensure that performances differences were not effect of differences in risk profiles, urgency and salience of stakeholder relations, the paper found significant evidence that banks were better off by adhering to their mandated community responsibilities.

More recently, Adamska and Dabrowski (2016) argued that investors focus on high CSR standards so that changes in the level of these standards is important information from investors' point of view, because these changes tend to be reflected in their performance. Applying an event study methodology, their results confirmed that investors on emerging markets take into account the information about changes in the level of corporate social responsibility and respond positively to its growth and negatively to its decline, thus, impacting on market value.

\section{Methodology}

\section{Data}

The elongated balanced panel data for the study was obtained from the Ghana Stock Exchange and other major depositories, such as the African Financial Market. The study period covered a time span of thirteen years; from $31^{\text {st }}$ December, 2004 to $31^{\text {st }}$ December, 20016 and includes all the six listed banks covering the period with 65 years' bank observations. Banks affected by acquisition were dropped. The CSR values together with such firm characteristics as bank variability, growth in interest income and bank size were extracted from the audited annual report and accounts of the listed banks. The closing market values for the various banks were also collected for the same period. These values do not include nontrading days, such as public holidays. 


\section{Variable description}

Two main types of variables were used in this study. These include both dependent and independent variables. The dependent variable was bank performance. The independent variable was sub-divided into main independent variable, which in this case was CSR, and controlled variables, such as bank variability, growth in interest income and bank size.

\section{Bank performance}

Bank performance in this study was measured by total marketto-total book value of the banks. Thus, if the market is correlated with superior and inferior CSR prospects (Adamska \& Dabrowski, 2016), it will also correlate with the banks' market-to-book value. The method has the advantage of capturing how the market evaluates each bank in terms of their strategic policies. It is also consistent with Ramchander, Schwebach and Staking's (2012) view that information disclosure on businesses is reflected in the market value of shares. Considering that most markets are inefficient, these strategic decisions may be difficult to process by stakeholders (Fama, Fisher, Jensen \& Roll, 1969), thus adversely affecting their market value. Based on these views and in line with the study objectives, bank performance was included as a dependent variable and examined.

Corporate social responsibility Corporate social responsibility in the Ghanaian banking sector is significantly expressed in socially responsible expenditures. It represents an integration of a heterogeneous element in such areas as education, healthcare, environment, and other stakeholder domains. This avoids the confusion in the use of ratings agency, like Kinder, Lydenberg, Domini (KLD) (Erhemjamts, Li, \& Venkateswaran, 2013), corporate reputational indices (CRI) by Fortune magazine (Preston \& O'Bannon, 1997) and questionnaire based measures (Gallardo-Vázquez \& Sanchez-Hernandez, 2014). The CSR variable was measured by aggregating all the expenditures and scaling same by pre-tax profits, consistent with prior studies, such as Campbell, Moore and Metzger (2002), and Ehsan and Kaleem (2012).

\section{Bank variability}

Bank variability in terms of risk has diverse impact on banks' 
market value and, consequently, on the ability to perform their CSR functions. On the one hand, if a bank manager finds that his or her bank experiences high levels of debt, it is likely that he or she will decrease CSR activities. This is because the bank will be forced to use its excess cash to honour interest obligations, and thus lack the funds to commit to CSR duties. On the other hand, if the bank manager realises that his or her risk level by way of debt is low, he or she is likely to increase his or her social performances. In view of these contrasting arguments, the variable has been controlled and in line with other previous studies (such as Waddock \& Graves, 1997; Seifert, Morris \& Bartkus, 2003; Saleh et al, 2010) in order to limit its influence on CSR-bank performance link. In the current study, bank variability was measured by dividing the banks' total asset by total equity.

\section{Growth}

This is another control variable included in the model. The variable was measured as a change in interest income (i.e., interest income $t_{t}$ - interest income $e_{t-1} /$ interest income $_{\text {- }}$ 1). A positive association indicates the banks' operational efficiency and the likelihood that the banks can engage in social activities. Conversely, a negative relationship implies an operational inefficiency and a disadvantage to corporate social performances due to inadequate available financial resources. With this latter option, CSR could not be a strategic choice.

Bank size

Evidence has shown that size plays a major role in both bank performance and CSR. Larger banks are easily visible and highly considered creditworthy, thus better resourced to increase their performance and satisfy societal demands. Smaller banks, on the other hand, may be more focused on establishing themselves and so may not have the necessary finances to be concerned about CSR. Size was also used in previous studies, such as Garcia-Castro, Arino and Canela (2010); Seifert, Morris and Bartkus (2004) and Waddock and Graves (1997). Size in this study was measured by taking the total asset of the banks.

\section{Data analysis}

An important step in the analysis of econometric data is to determine the order of integration through unit root testing. This is critical, because the order of 
integration indicates the appropriate statistical estimator to employ so as to avoid spurious regression. Engle and Granger (1987) argued that spurious regression estimates tend to produce performance statistics that are inflated, thus causing researchers to commit high frequency of Type 1 errors (Granger \& Newbold, 1974). As a result, two categories of panel unit root tests were performed: Levin, Lin and Chu's (2002) (LLC) test, which followed a common unit root process and Im, Pesaran, and Shin's (2003) test (IPS), and Maddala and Wu's (1999) Fisher type ADF and PP tests, which test for individual unit root processes in heterogeneous data.

\section{Cointegration test}

Since all the variables followed an I (1) process, a cointegration test became necessary. In this regard, Kao (1999) cointegration approach was used to test the cointegration (interdependence) among the variables. The method was chosen because Gutierrez (2003) compared the power of various panel cointegration test statistics and found that Kao's test has higher power than other cointegration tests. The residual based Kao (1999) cointegration test tests the cointegration between the dependent variable (bank performance) and the independent variables (CSR, bank variability, growth in interest income and bank size). Kao's proposition followed Augmented Dickey-Fuller (ADF) panel cointegration test, where cointegrating vectors are assumed to behave homogeneously. Consider equation 1 .

$$
\eta_{i t}=\vartheta_{i}+\phi \mu_{t}+\zeta_{i t}
$$

Equation 1

Where $\eta$ is the dependent variable (bank performance), $\vartheta_{i}$ is the intercept, $\phi$ is the co-efficient of the independent variables, $\mu$ represents the independent variables (CSR, bank variability, growth in interest income and bank size), it is the cross-sectional time series, and $\zeta$ as estimated residual. With $\eta$ and $\mu$ following an $\mathrm{I}(1)$ process or integrated of order 1 , the ADF test applicable to the re-parameterized residual is shown in equation 2 .

$$
\zeta_{i t}=\eta \zeta_{i t}-1+\sum_{j-1}^{\beta} \varphi_{j} \Delta \zeta_{i t}-j+\alpha_{i t} \beta
$$

$$
\text { Equation } 2
$$


Where, $\beta$ is used so that $\alpha i t \beta$ becomes serially uncorrelated, and the estimated residual of $\sum_{j-1}^{\beta} \varphi_{j} \Delta \zeta_{i t-j}$ included as the first difference of 1 to $\beta$ lags. The formulated null hypothesis of no cointegration is $H_{0}: p=1$. This is rejected if the probability value is less than $5 \%$ or fails to be rejected if the probability value is greater than $5 \%$.

\section{Econometric model}

Given the evidence of cointegration, the Pooled Mean Group (PMG)/Panel ARDL by Pesaran, Shin and Smith (1999) was employed as the appropriate estimating technique to examine the short- and long-run relationships. The model involves pooling and averaging so that the intercepts, short-run coefficients and error variances differ freely across banks, while the long run coefficients are constrained to be the same. The PMG/Panel ARDL model was deemed suitable for this study, because both the short- and long-run specifications can be generated simultaneously irrespective of whether the variables are $\mathrm{I}(0)$ or $\mathrm{I}(1)$. The method is also capable of tackling endogeneity, thus producing best linear unbiased estimators. Following Pesaran et al (1999), the general model is specified as:

$$
C i t=\theta_{0 i}+\theta_{1 i} y_{i t}^{d}+\theta_{2 i} \prod_{i t}+\theta_{3 i} \alpha_{i t}+\theta_{4 i} \beta_{i t}+\mu_{i t}, \quad i=1,2 \ldots . . N, t=1,2, \ldots \ldots T,
$$

\section{...... Equation 3}

Where

Cit = natural logarithm of bank performance proxy by market-tobook value (MBV) for bank $i$ in period $t$

$y_{i t}^{d}=$ natural logarithm of corporate social responsibility $\left(\mathrm{CSR}^{\wedge} 2\right)$ for bank $i$ in period $t$ $\prod i t=$ natural logarithm of bank variability (BV) for bank $i$ in period $t$

cit $=$ natural logarithm of growth in interest income $\left(\mathrm{G}^{\wedge} 2\right)$ for bank $i$ in period $t$

$\beta i t=$ natural logarithm of bank size (SIZE) for bank $i$ in period $t$

$\theta_{0} i=$ intercept 
$\theta_{1} i-\theta_{4} i=$ parameters to be estimated

$\mu i t=$ stochastic term for bank $i$ in period $t$

In equation 3 , the natural logarithms were applied so that they can be interpreted as elasticities and help to eliminate heteroscedsticity in the disturbances (Adams \&
Hardwick, 1998). CSR and growth in interest income were transformed by taking the square values before applying the log, since some of the banks recorded losses at some points in their operations. In applying equation 3, a maximum lag length of one was automatically selected based on the unrestricted model by Akaike info criterion (AIC). Therefore, the ARDL $(1,1,1,1,1)$ equation is:

$L M B V_{i t}=\theta_{0 i}+\psi_{10 i} L C S R^{\wedge} 2_{i t}+\psi_{11 i} L C S R^{\wedge} 2_{i t-1}+\psi_{20 i} L B V_{i t}+\psi_{21 i} L B V_{i t-1}+\psi_{30 i} L G^{\wedge} 2_{i t}+\psi_{31 i} L G^{\wedge} 2_{i t-1}$ $+\psi_{40 i} L S I Z E_{i t}+\psi_{41 i} L S I Z E_{i t}+\lambda_{i} L M B V_{i t}-1+\varepsilon_{i t}$ Equation 4

The error correction model as given in equation 5 , with $\Delta$ indicating first difference or I(1) is:

$\triangle L M B Y_{i t}=\phi_{i}\left(L M B V_{i t-1}-\theta_{0 i}-\theta_{1 i} L C S R^{\wedge} 2_{i t}-\theta_{2 i} L B V_{i t}-\theta_{3 i} L G^{\wedge} 2_{i t}-\theta_{4 i} L S I Z E_{i t}\right)-\psi_{11 i} L L C S R^{\wedge} 2_{i t}-$ $\psi_{21 i} \Delta L B V_{i t}-\psi_{31 i} \Delta L G^{\wedge}{ }{ }_{i t}-\psi_{41}{ }_{1 i} \Delta L S I Z E_{i t}+\varepsilon_{i t}$, Equation 5

Also, that the estimated intercept in equation 4 becomes:

$\theta_{0} i=\frac{\mu_{i}}{1-\lambda_{i}}, \theta_{1 i}=\frac{\psi_{10 i}+\psi_{11 i}}{1-\lambda_{i}}, \theta_{2 i}=\frac{\psi_{20 i}+\psi_{21 i}}{1-\lambda_{i}}, \theta_{3 i}=\frac{\psi_{30 i}+\psi_{31 i}}{1-\lambda_{i}}, \theta_{4 i}=\frac{\psi_{40 i}+\psi_{41 i}}{1-\lambda_{i}}, \phi_{i}=-\left(1-\lambda_{i}\right)$. .. $\quad$.... Equation 6

In equation 6, the banks' specific error correction co-efficient, $\phi_{i}=-\left(1-\lambda_{i}\right)$ must lie between -1 and 0 and significant for three main reasons: to indicate speed of adjustment to equilibrium in the long run and confirm both long run and cointegration among the variables. The models were tested at a specific alpha level of 5\%. (See Table 1.) 
Table 1: A priori effect

\begin{tabular}{ll}
\hline Variable & A priori effect with bank performance \\
\hline Corporate social responsibility & Positive/Negative \\
Bank variability & Negative \\
Growth in interest income & Negative \\
Bank size & Positive \\
\hline
\end{tabular}

\section{Results and Discussion}

Before the results of the short- and long-term effects of CSR on the performance of the listed banks in Ghana are presented, the basic characteristics of the variables in nominal or original form are, first of all, shown in Table 2 as the summary of descriptive statistics.

Table 2: Summary of descriptive statistics

\begin{tabular}{lcccc}
\hline & $\mathrm{MBV}_{\mathrm{it}}$ & $\mathrm{CSR}^{\wedge} 2_{\mathrm{it}}$ & $\mathrm{BV}_{\mathrm{it}}$ & $\mathrm{G}^{\wedge} 2_{\mathrm{it}}$ \\
$\mathrm{SIZE}_{\text {it }}$ & & & & \\
\hline $\begin{array}{l}\text { Mean } \\
\text { 1.43E+09 }\end{array}$ & 2.5514 & 0.0067 & 7.6491 & 0.2818 \\
$\begin{array}{l}\text { Median } \\
\text { 9.73E+08 }\end{array}$ & 1.8858 & 0.0042 & 7.3384 & 0.2176 \\
$\begin{array}{l}\text { Maximum } \\
\text { 65E+09 }\end{array}$ & 10.3221 & 0.0284 & 14.4835 & 0.9429 \\
$\begin{array}{l}\text { Minimum } \\
\text { 59349235 }\end{array}$ & 0.5937 & -0.0107 & 4.6153 & -0.3404 \\
$\begin{array}{l}\text { St. dev. } \\
1.34 \mathrm{E}+09\end{array}$ & 1.8134 & 0.0074 & 2.0933 & 0.2491 \\
$\begin{array}{l}\text { Qt. dev. } \\
780652993\end{array}$ & 1.0666 & 0.0045 & 1.2377 & 0.1707 \\
$\begin{array}{l}\text { Skewness } \\
1.2719\end{array}$ & 1.8248 & 0.9998 & 1.2826 & 0.4548 \\
\hline
\end{tabular}

Source: Annual reports 2004-2016

From Table 2, it is evident that the median performance of the listed banks during the study periods (i.e., 2004-2016) using market-tobook value is 1.8858 with a quartile deviation of 1.0666 . This means that 
the market value of the banks exceeded the book value by approximately $89 \%$, an indication that these banks during the study period have created value for their investors. This result means that equity investors of the listed banks have earned about 89 pesewas for every cedi of net asset over the study periods - a general indication that investors valued the banks' stocks favourably. The median CSR expenditure incurred is 0.0042 with a quartile deviation of 0.0045 . Overall, the average amount of social contributions made by the banks is low in Ghana. On the other hand, the average rate of bank variability (risk) recorded is 7.3384 and has a quartile deviation of 1.2377. The bank variability outcome is critical, because it showed that, over the study periods, more than sevenfold of the banks' assets are financed by debt. More so, while the banks grew at an average of 0.2818 with a dispersion of 0.2491 , the average size of the banks was $97,300,000,000$ Ghana cedis with 780652993 as its quartile deviation.

\section{Correlation Matrix}

In order to ensure that the variables included in the model are not highly correlated, the correlation matrix has been produced. From Table 3, the results have not shown any evidence that the correlations are too high. The correlation between bank variability and bank size, for example, is 0.0155 , which is less than 0.7 , therefore, all the variables have been retained. 
Table 3: Correlation Matrix Results

\begin{tabular}{llllll}
\hline Variable & $\mathrm{LMBV}_{\text {it }}$ & $\mathrm{LCSR}^{\wedge} 2_{\text {it }}$ & $\mathrm{LBV}_{\text {it }}$ & $\mathrm{LG}^{\wedge} 2_{\text {it }}$ & $\mathrm{LSIZE}_{\text {it }}$ \\
\hline $\mathrm{LMBV}_{\text {it }}$ & 1.0000 & & & & \\
$\mathrm{LCSR}^{\wedge} 2_{\text {it }}$ & -0.1849 & 1.0000 & & & \\
& $(0.1402)$ & & & & \\
$\mathrm{LBV}_{\text {it }}$ & 0.3169 & 0.2482 & 1.0000 & & \\
& $(0.0101)$ & $(0.0462)$ & & & \\
$\mathrm{LG}^{\wedge} 2_{\text {it }}$ & -0.2313 & -0.0140 & -0.1237 & 1.0000 & \\
& $(0.0637)$ & $(0.9116)$ & $(0.3261)$ & 1.0000 & \\
$\mathrm{LSIZE}_{\text {it }}$ & -0.3117 & -0.3345 & 0.0155 & 0.2594 & 1.0000 \\
& $(0.0115)$ & $(0.0065)$ & $(0.9022)$ & $(0.0368)$ & \\
& & & & &
\end{tabular}

Source: Annual reports 2004-2016

Panel unit root test results

Table 4 displays the test results for the stationarity of the variables, as indicated in the previous sections. The results in Table 4 suggest that at $5 \%$ significant level, the variables: bank performance $\left(\mathrm{LMBV}_{\mathrm{it}}\right), \quad$ corporate social responsibility $\left(\mathrm{LCSR}^{\wedge} 2_{\mathrm{it}}\right)$ and growth in interest income $\left(\mathrm{LG}^{\wedge} 2_{\mathrm{it}}\right)$ are integrated at levels, whilst bank variability $\left(\mathrm{LBV}_{\mathrm{it}}\right)$ and bank size
$\left(\mathrm{LSIZE}_{\mathrm{it}}\right)$ are non-stationary. At first difference, however, all the variables were integrated at I (1). Although the PMG/Panel ARDL model holds regardless of whether the order of integration is $\mathrm{I}(0)$ or $\mathrm{I}(1)$, the first difference was necessary to ensure that none of the variables was I(2) or higher to invalidate the computed Fstatistics and, subsequently, test for both the cointegration relationship and its effects. 
Table 4: Panel unit root tests results at levels and first difference

\begin{tabular}{|c|c|c|c|c|}
\hline $\begin{array}{l}\text { Variables } \\
\text { Fisher }\end{array}$ & Levin, Lin \& Chu & Im, Pesaran \& Shin & ADF-Fisher & PP- \\
\hline \multicolumn{5}{|l|}{ At levels } \\
\hline $\mathrm{LMBV}_{\text {it }}$ & 0.0002 & 0.0177 & 0.0391 & 0.0330 \\
\hline $\operatorname{LCSR}^{\wedge} 2_{\mathrm{it}}$ & 0.0021 & 0.0162 & 0.0261 & 0.0113 \\
\hline $\mathrm{LBV}_{\text {it }}$ & 0.1836 & 0.3563 & 0.4609 & 0.5316 \\
\hline $\mathrm{LG}^{\wedge} 2_{\mathrm{it}}$ & 0.0000 & 0.0000 & 0.0000 & 0.0000 \\
\hline LSIZE $_{i t}$ & 0.1542 & 0.9650 & 0.9460 & 0.6490 \\
\hline \multicolumn{5}{|c|}{ At first difference } \\
\hline$\Delta \mathrm{LMBV}_{\text {it }}$ & 0.0000 & 0.0000 & 0.0000 & 0.0000 \\
\hline$\Delta \operatorname{LCSR}^{\wedge} 2_{\mathrm{it}}$ & 0.0000 & 0.0000 & 0.0000 & 0.0000 \\
\hline$\Delta$ LBVit & 0.0000 & 0.0000 & 0.0000 & 0.0000 \\
\hline$\Delta \mathrm{LG}^{\wedge} 2_{\mathrm{it}}$ & 0.0000 & 0.0000 & 0.0000 & 0.0000 \\
\hline$\Delta$ LSIZE $_{\text {it }}$ & 0.0000 & 0.0000 & 0.0000 & 0.0000 \\
\hline
\end{tabular}

Note: Only the probability values are shown

Source: Annual reports 2004-2016

\section{Co-integration test results}

Next, the co-integration test results estimated using Kao (1999) are displayed in Table 5. It tested the co-integration between the dependent variable (bank performance) and the independent variables (CSR, bank variability, growth in interest income and bank size), to determine if these variables move together in the long term. The null hypothesis is that there is no cointegration $(\mathrm{r}=0)$ at $5 \%$ significant level. The automatic lag length was selected based on Schwartz Information Criterion (SIC) with a maximum lag of 2. Starting with the null hypothesis of no cointegration $(\mathrm{r}=0)$ among the variables, the probability value, 0.0031 , is less than the 5\% significant level. Thus, the null hypothesis of no cointegration is rejected. Thus, this study concludes that a long term cointegration relationship exists among the series bank performance ( $\triangle$ LMBVit), corporate social responsibility $(\Delta$ LCSRit), bank variability $(\Delta$ LMBVit), growth in interest income ( $\Delta$ LGit) and bank size ( $\Delta$ LSIZEit). 
Table 5: Kao residual cointegration test

T-Stat.

Prob.

\begin{tabular}{|c|c|c|c|c|}
\hline ADF & & & & -2.7340 \\
\hline 0.0031 & & & & \\
\hline Residual variance & & & & 286 \\
\hline HAC variance & & & & 864 \\
\hline Augmented Dicky-F & ler Test Equ & & & \\
\hline Dependent Variable: & (RESID) & & & \\
\hline Variable & Coefficient & Std. Error & T-Stat. & Prob. \\
\hline RESID(-1) & -1.1762 & 0.1278 & -9.2026 & 0.0000 \\
\hline $\mathrm{R}$-squared & 0.6099 & & & \\
\hline Adjusted R-squared & 0.5919 & & & \\
\hline Durbin-Watson stat. & 2.3211 & & & \\
\hline
\end{tabular}

Source: Annual reports 2004-2016

First, the estimated regression results of the PMG/Panel ARDL $(1,1,1,1,1)$ model, using Pesaran et al (1999), are shown in Table 6. Both the short- and the longrun outcomes have been reported. The banks' specific error correction co-efficient (-0.7729) is also shown.
As expected, the error correction coefficient lies between -1 and 0 , negative and significant at five percent alpha level (0.0150). The error correction co-efficient confirmed existence of cointegration and a return to equilibrium should there be any deviation.

Table 6: PMG/Panel ARDL results

$$
\text { Dependent variable }=\Delta \mathrm{LMBV}_{\text {it }}
$$

Short run equation

\begin{tabular}{lccr} 
Variables & Coefficients & Standard error & Probability \\
COINTEQ01 & -0.7729 & 0.3002 & 0.0150 \\
$\Delta \mathrm{LCSR}^{\wedge} 2_{\text {it }}$ & 0.0861 & 0.0864 & 0.3266 \\
$\Delta \mathrm{LBV}_{\text {it }}$ & 0.6022 & 0.6454 & 0.3580 \\
$\Delta \mathrm{LG}^{\wedge} 2_{\text {it }}$ & -0.0468 & 0.0174 & 0.0115 \\
$\Delta \mathrm{LSIZE}_{\mathrm{it}}$ & -1.3344 & 0.5307 & 0.0173 \\
\hline
\end{tabular}


Long run equation

$\begin{array}{lccc}\mathrm{LCSR}^{\wedge} 2_{\text {it }} & -0.1881 & 0.0426 & 0.0001 \\ \mathrm{LBV}_{\text {it }} & 0.9947 & 0.2619 & 0.0006 \\ \mathrm{LG}^{\wedge} 2_{i t} & 0.1912 & 0.0251 & 0.0000 \\ \mathrm{LSIZE}_{\text {it }} & -0.2958 & 0.0417 & 0.0000 \\ \mathrm{C} & 2.7095 & 0.9298 & 0.0066\end{array}$

Mean dependent var -0.1258

S.E. of regression $\quad 0.2753$

Sum squared resid $\quad 2.3496$

Log likelihood $\quad 13.086$
S.D. dependent var

0.4494

Akaike info criterion $\quad 0.6435$

Schwarz criterion

1.7808

Hannan-Quinn criterion

Source: Annual reports 2004-2016

As can be seen from Table 6, the short run relationship between the natural $\log$ of CSR and bank performance (measured by marketto-book value) indicates a positive but insignificant effect at an alpha level of 5\%, controlling for natural $\log$ of bank variability, growth in interest income and bank size. The implication is that even though a one percent increase in CSR would have resulted in approximately $0.0861 \%$ increase in bank performance (i.e., market-to-book value), all things being equal, the increase is scientifically not different from zero (probability $=0.3266$ ). The result thus strongly supports the null hypothesis 1 , which states that there is no significant short-run effect of
CSR on bank performance. The argument that improved social performance leads to increase bank performance remained statistically unproven in this study. CSR could be necessary in the short run, but not a sufficient condition to attract the desired positive impact. The finding also failed to provide support for either the Shareholder theory or the Stakeholder theory in the short run. Thus the position of shareholder theorists, such as, Levitt (1958), Friedman (1962, 1970) and such stakeholder theorists, like Donaldson and Preston (1995), Freeman (1984), Harris and Freeman (2008), and Phillips, Freeman and Wicks (2003), have been contradicted by this result. 
In the second hypothesis, the proposition was that there is no significant long-run effect of CSR on bank performance. While, again, holding natural $\log$ of bank variability, growth in interest income and bank size constant, the PMG/Panel ARDL regression result generally showed that the natural log of CSR has a significant negative effect on natural $\log$ of bank performance, using market-to-book measure at an alpha level of $5 \%$. In this regard, a one percent increase in CSR will result in about $0.1881 \%$ decrease in bank performance (market-to-book value) in the long run, all things being equal (probability $=0.0001$ ). In the long run, banks' social performances, in terms of philanthropic donations, are negatively evaluated by stakeholders and so become a cost to investors. Two main reasons might be responsible for this effect. Firstly, the signals of CSR performance sent to the equity market did not systematically correlate with the banks' economic fundamentals (Orliztky, 2013). Secondly, the possibility of market imperfection could also not be ignored. Based on this finding, null hypothesis 2 is rejected. There exists a significant relationship so that, in the long run,
CSR negatively affects bank performance. This long-run outcome, therefore, aligned strongly with the Shareholder theory and the subsequent positions of Levitt (1958) and Friedman (1962, 1970), that so long as the social activities do not increase the value of the banks, they represent cost and must not be encouraged.

\section{Conclusion}

The present study provided evidence on how CSR undertakings affect listed banks in Ghana in the short and long term. The major conclusion is that, in the long term, CSR significantly reduces bank performance. Being sociallyinvolved listed bank affects investors in the long run. In this regard, the study offers policy implications for the bank managers and scholars alike.

Managers of the banks need to understand that CSR performance needs to be carefully planned and implemented to serve as a boost to bank performance and not just regarded as an inconsequential addendum. More so, scholars must not only concentrate on the shortterm position of CSR as it is currently done, but seek to determine if the 
Gartchie Gasti: Corporate Social Responsibility and Bank Performance: ...

short-term relationships hold consistently over time. 


\section{References}

Ackermann, F., \& Eden, C. (2011). Strategic management of stakeholders: Theory and practice. Long range planning, 44(3), 179-196.

Adams, M., \& Hardwick, P. (1998). An analysis of corporate donations: United Kingdom evidence. Journal of management Studies, 35(5), 641-654.

Adamska, A., \& Dabrowski, T. J. (2016). Do Investors Appreciate Information about Corporate Social Responsibility? Evidence from the Polish Equity Market. Inzinerine

Ekonomika/Engineering Economics, 27(4), 364-372.

Ahmed, S. U., Islam, M. Z., \& Hasan, I. (2012). Corporate Social Responsibility and Financial Performance LinkageEvidence from the Banking Sector of Bangladesh. Journal of Organizational Management, 1 (1), 14-21.

Amidu, M. (2007). Determinant of Capital Structure of Banks in Ghana: An Empirical Approach. Baltic Journal of Management, 2 (1), 66-79.
Amran, A., Ling, L. L., \& Sofri, Y. (2007). A study of corporate philanthropic traits among major Malaysian corporations. Social Responsibility Journal, 3(4), 21-30.

Barnett, M. L., \& Salomon, R. M. (2003). Throwing a Curve at Socially Responsible Investing Research. Organization \& Environment, 16 (3), 381389.

Boatright, J. R. (1994). Fiduciary Duties and the ShareholderManagement Relation: Or, what's so special about Shareholders? Business Ethics Quarterly, 4 (4), 393 407.

Bowen, H. R. (1953). Social responsibilities of the businessman. New York: Harper \& Row

Campbell, D., Moore, G., \& Metzger, M. (2002). Corporate philanthropy in the UK 1985-2000 some empirical findings. Journal of Business Ethics, 39(1-2), 29-41.

Carroll, A. B. (1979). A threedimensional conceptual model of corporate 
performance. Academy of management review, 4(4), 497-505.

Carroll, A. B. (1981). Business and society: managing corporate social performance. Boston: Little, Brown.

Carroll, A. B. (1991). The pyramid of corporate social responsibility: Toward the moral management of organizational stakeholders. Business horizons, 34(4), 39-48.

Carroll, A. B., \& Shabana, K. M. (2010). The business case for corporate social responsibility: A review of concepts, research and practice. International journal of management reviews, 12(1), 85-105.

Ciciretti, R., Kobeissi, N., \& Zhu, Y. (2014). Corporate social responsibility and financial performance: an analysis of bank community responsibility. International Journal of Banking, Accounting and Finance, 5(4), 342-373.

Coase, R. H. (1937). The nature of the firm. economica, 4(16), 386-405.
Doh, J. P., Howton, S. D., Howton, S. W., \& Siegel, D. S. (2010). Does the market respond to an endorsement of social responsibility? The role of institutions, information, and legitimacy. Journal of Management, 36(6), 14611485.

Donaldson, T., \& Preston, L. E. (1995). The stakeholder theory of the corporation: Concepts, evidence, and implications. Academy of management Review, 20(1), 65-91.

Ehsan, S., \& Kaleem, A. (2012). An Empirical Investigation of the Relationship between Corporate Social Responsibility and Financial Performance (Evidence from Manufacturing Sector of Pakistan). Journal of Basic and Applied Scientific Research, 2(3), 2909-2922.

Ehrlich, C. (2005). Is Business Ethics Necessary? DePaul Business and Commercial Law Journal, 4(1), 55.

Engle, R. F., \& Granger, C. W. J. (1987). Co-integration and Error Correction: Representation, Estimation, 
Gartchie Gasti: Corporate Social Responsibility and Bank Performance: ...

and Testing. Econometrica, 55, 251-276.

Erhemjamts, O., Li, Q., \& Venkateswaran, A. (2013). Corporate social responsibility and its impact on firms' investment policy, organizational structure, and performance. Journal of business ethics, 118(2), 395412.

Fisch, J. E. (2006). Robert Clark's Corporate Law: Twenty Years of Change: Measuring Efficiency in Corporate Law: The Role of Shareholder Primacy. Iowa Journal of Corporation Law, 31, 637.

Freeman, R. E. (1994). The politics of stakeholder theory: some future directions. Business Ethics Quarterly, 4, 409421.

Friedman, M. (1970). The Social Responsibility of Business is to Increase its Profits. New York Times Magaziness, 122-126.

Friedman, M. (1962). Capitalism and Freedom. Chicago, IL: The University of Chicago Press. Gallardo-Vázquez, D., \& SanchezHernandez, M. I. (2014). Measuring corporate social responsibility for competitive success at a regional level. Journal of Cleaner Production, 72,1422.

Garcia-Castro, R., Ariño, M. A., \& Canela, M. A. (2010). Does social performance really lead to financial performance? Accounting for endogeneity. Journal of Business Ethics, 92(1), 107126.

Gatsi, J. G. (2012). Capital structure of Ghanaian banks: An evaluation of its impact on performance. IUP Journal of Bank Management, 11(4), 86.

Giving U.S.A. (2012). Donations Barely Grew at All Last Year. Web. Accessed January 17, 2018. $<$ http://philanthropy.com/art icle/Donations-BarelyGrew-at All/132367/>.

Godfrey, P. C., Merrill, C. B., \& Hansen, J. M. (2009). The relationship between corporate social responsibility and shareholder value: an empirical test of the risk management hypothesis. 
Gartchie Gasti: Corporate Social Responsibility and Bank Performance: ...

Strategic Management

Journal, 30 (4), 425 - 445.

Gutierrez, L. (2003). On the power of panel cointegration tests: a Monte Carlo comparison. Economics Letters, 80(1), 105-111.

Harris, J. D., \& Freeman, R. E. (2008). The impossibility of the separation thesis: A response to Joakim Sandberg. Business Ethics Quarterly, 18(4), 541-548

Hazlitt, H. (1952). Economics in one lesson. Irvington-on Hudson, New York: Foundation for Economic Education

Hinson, R. \& Adjasi, C. K. D. (2009). The internet and export: some cross-country evidence from selected African countries, Journal of Internet Commerce, 8 (3), $309-24$.

Hinson, R. E., Agbleze, S., \& Kuada, J. (2013). Perspective on Corporate Social Responsibility (CCSR) Employer Attractiveness: Conference Paper presented at the $14^{\text {th }}$ IAABD in Accra, Ghana.
Hinson, R., Boateng, R., \& Madichie, N. (2010). Corporate social responsibility activity reportage on bank websites in Ghana. International Journal of Bank Marketing, 28(7), 498-518.

Hye, Q. M. A., \& Dolgopolova, I. (2011). Economics, finance and development in China Johansen-Juselius cointegration approach. Chinese Management Studies, 5(3) , 311-324

Im, K. S., Pesaran, M. H., \& Shin, Y. (2003). Testing for unit roots in heterogeneous panels. Journal of econometrics, 115(1), 5374.

Jensen, M. C. (2001). Value Maximization, Stakeholder Theory, and the Corporate Objective Function. European Financial Management, 7 (3), 297317.

Jones, T. M. (1980). Corporate social responsibility revisited, redefined. California management review, 22(3), 59-67.

Kao, C. (1999). Spurious regression and residual-based tests for cointegration in panel 
Gartchie Gasti: Corporate Social Responsibility and Bank Performance: ...

data. Journal

of

econometrics, 90(1), 1-44.

Keffas, G., \& Olulu-Briggs, O. (2011). Corporate social responsibility: how does it affect the financial performance of banks? Empirical evidence from US, UK and Japan. Journal of management and corporate governance, 3(2), 8-26

Kuada, J., \& Hinson, R. (2012). Corporate social responsibility (CSR) practices of foreign and local companies in Ghana. Thunderbird International Business Review, 54 (4), 521-536.

Lentner, C., Szegedi, K., \& Tibor, T. (2015). Corporate Social Responsibility in the Banking Sector. Public Finance Quarterly, 1(1),95103.

Levin, A., Lin, C. F., \& Chu, C. S. J. (2002). Unit root tests in panel data: asymptotic and finite-sample properties. Journal econometrics, 108(1), 1-24.

Levitt, T. (1958). The dangers of social responsibility.
Harvard Business Review, 36 (5), 41-50.

Luo, X., \& Bhattacharya, C. (2009).

The debate over doing good:

Corporate social

performance, strategic marketing levers, and firmidiosyncratic risk. Journal of marketing, 73(6), 198-213.

Mackey, A., Mackey, T. B., \& Barney, J. B. (2007). Corporate social responsibility and firm performance: Investor preferences and corporate strategies. Academy of Management Review, 32(3), 817-835.

Maddala, G. S., \& Wu, S. (1999). A comparative study of unit root tests with panel data and a new simple test. Oxford Bulletin of Economics and statistics, 61(S1), 631-652.

Margolis, J. D., \& Walsh, J. P. (2003). Misery loves companies: rethinking social initiatives by business. Administrative Science Quarterly, 48(2), 268-306.

Markowitz, H. M. (1952). Portfolio selection. Journal of Finance, 7(1), 77-91.

McGuire, J. B., Sundgren, A., \& Schneeweis, T. (1988). 
Gartchie Gasti: Corporate Social Responsibility and Bank Performance: ...

Corporate social responsibility and firm financial

performance. Academy of management Journal, 31(4), 854-872.

Modigliani, F., \& Miller, M. H. (1958). The cost of capital, corporation finance and the theory of investment. The American economic review, 48(3), 261-297

Ofori, D. F., \& Hinson, R. E. (2007). Corporate social responsibility (CSR) perspectives of leading firms in Ghana, Corporate Governance: The international Journal of Business in Society, 7(2), $178-193$.

Orlitzky, M. (2005). Social responsibility and financial performance: Trade-off or virtuous circle. University of Auckland

Business

Review, 7(1), 37-43.

Orliztky, M. (2013). Corporate Social Responsibility, Noise, and Stock Market Volatility. The Academy of $M$ anagement Perspectives, 27(3), $238-254$.

Orlitzky, M., \& Benjamin, J. D. (2001). Corporate social performance and firm risk: A meta-analytic review. Business \& Society, 40(4), 369-396.

Orlitzky, M., Schmidt, F. L., \& Rynes, S. L. (2003). Corporate social and financial performance: A meta-analysis. Organization Studies, 24(3), 403-441.

Palepu, K. G., Healy, P. M., \& Peek, E. (2010). Business Analysis and Valuation. Hampshire: Cengage learning.

Pesaran, M. H., Shin, Y., \& Smith, R. P. (1999). Pooled mean group estimation of dynamic heterogeneous panels. Journal of the American Statistical Association, 94(446),621 -634.

Phillips, R. R. Freeman, E., \& Wicks, A. C. (2003). What Stakeholder Theory is not. Business Ethics Quarterly, 13 (4), 479-502.

Ramchander, S., Schwebach, R. G., \& Staking, K. (2012). The informational relevance of corporate social responsibility: evidence from DS400 index reconstitutions. Strategic Management Journal, 33 (3), 303-314. 
Gartchie Gasti: Corporate Social Responsibility and Bank Performance: ...

Reinhardt, F. L., \& Stavins, R. N. (2010). Corporate social responsibility, business strategy, and the environment. Oxford Review of Economic Policy, 26 (2),164-181.

Saleh, M., Zulkifli, N., \& Muhamad, R. (2010). Corporate social responsibility disclosure and its relation on institutional ownership Evidence from public listed companies in Malaysia. Managerial Auditing Journal, 25 (6), $591-613$.

Sundaram, A. K., \& Inkpen, A. C. (2004). Stakeholder Theory and The Corporate Objective Revisited: A Reply. Organization Science, 15 (3), 370-371.

Tuokuu, F. X. D., \& AmponsahTawiah, K. (2016). Corporate social responsibility: is it an alternative to government? Journal of Global Responsibility, 7(1), 26-38.

Seifert, B., Morris, S. A., \& Bartkus, B. R. (2003). Comparing big givers and small givers: Financial correlates of corporate philanthropy. Journal of business ethics, 45(3), 195211.

Vilanova, M., Lozano, J. M., \& Arenas, D. (2009). Exploring the nature of the relationship between CSR and competitiveness. Journal of Business Ethics, 87(1), 5769.

Von Arx, U., \& Ziegler, A. (2014). The Effect of CSR on Stock Performance: New Evidence for the USA and Europe. Quantitative Finance, 14(6),977-991.

Waddock, S. A., \& Graves, S. B. (1997). The corporate social performance-financial performance link. Strategic management journal, 18(4), 303-319.

Wible, J. R. (1982). Friedman's positive economics and philosophy of science. Southern Economic Journal, 49(2), 350-360.

Wicks, A. C. (1996). Overcoming the separation thesis: the needfor a reconsideration of business and society research. Business \& Society, 35(1), 89-118.

Zhang, J., Yang, B., \& Wang, F. (2012). 
Gartchie Gasti: Corporate Social Responsibility and Bank Performance: ...

Philanthropic Giving:

Active Responsibility or

Passive Ingratiation?

Evidence from Chinese

Family-Controlled Listed

Companies. The Journal of

Applied Business Research, 28 (8) 427-440. 